\title{
Application of the Building Height Concept to Energy-Efficient Heating and Cooling for Saharan Buildings
}

\author{
Abdelaziz Benkhelifa ${ }^{1,2}$, Sidi Mohammed El Amine Bekkouche ${ }^{2 *}$, Tayeb Allaoui ${ }^{1}$, Mohamed Kamal Cherier ${ }^{2}$, \\ Maamar Hamdani ${ }^{2}$, Redouane Mihoub ${ }^{2}$, Rachid Djeffal ${ }^{2}$ \\ ${ }^{1}$ Laboratory of Electrical and Computer Engineering (L2GEGI) Ibn Kaldoun University, BP P78 Zaaroura 14000, Tiaret, \\ Algeria \\ ${ }^{2}$ Unité de Recherche Appliquée en Energies Renouvelables, URAER, Centre de Développement des Energies Renouvelables, \\ CDER, 47133, Ghardaïa, Algeria
}

Corresponding Author Email: smabekkouche@gmail.com

https://doi.org/10.18280/mmc_c.802-405

Received: 9 April 2019

Accepted: 25 August 2019

\section{Keywords:}

energy needs, compactness, thermal insulation, building height concept, storeys, energy saving, investment-return time

\begin{abstract}
The compactness of a building depends on its shape, its size and its contact properties The main objective of this contribution is to investigate the impact of the building' height on energy needs. The assessment criteria will be based on a well-defined lifestyle and occupancy scenario, the indoor comfort temperature and the required energy consumption. The results obtained from the regression models and their relative simplicity allows them to be used as a tool for estimating energy needs, energy savings and investment-return time. The absence of insulation would result in an energy saving of exactly $26.77 \%$, by raising a single house to one-storey building. It will be more substantial savings (more than $40 \%$ ) by exceeding the fourth floor. In the case of an insulating layer of $10 \mathrm{~cm}$, an energy gain of $21.17 \%$ can be saved by varying a single house to one-storey building. The reduction in energy needs exceeds $35 \%$ but remains below $38.5 \%$ for buildings which are over three storeys high. Generally, the investment-return time is between 49 months and 44 months, and it is inversely proportional to the number of storeys in the dwelling. It is therefore necessary to favor large buildings to rationalize energy consumption.
\end{abstract}

\section{INTRODUCTION}

The intensive use of energies from exhaustible natural resources has motivated some scientists to propose experimental environmental works on atmospheric emissions in urban areas [1]. In this context, the geometry of thermal structures is an essential factor in determining the reached comfort. The shape factor is a measure of the building's compactness. According to a literature review, several contributions have revealed that the building design has a significant effect on both the thermal performance and energy needs. Martaa and Belinda [2] have proposed a simplified model to expect heating and cooling energy needs for a building subject to a Spanish climate. They reported that the compactness factor is one of the determining and preponderant factors. Li et al. [3] have provided some guidelines which enable to compute shape compactness based on the inertia moment. As expected in reference [4], it is proved that the stated concepts that have a direct link with the geometric properties can improve the energy efficiency in buildings. In 2012, on the basis of the research studies achieved by Parasonis et al. [5], it has been indicated that the relationship between the building shape and its energy performance was significant. On the one hand, the geometric efficiency depends both on its dimensions and proportions; on the other hand heat losses through the envelope elements constitute a large part of the total energy needs. However, in some Algerian sites, such as Algiers and Ghardaïa, optimal compactness is an additional measure to consider; increasing the compactness index has a contrasting effect, negative for the heating and positive for the cooling, meanwhile, the savings for cooling needs are larger than the disadvantage of increased heating needs [6]. Other research work, conducted by Ourghi et al. [7] allowed us to obtain an analysis tool to predict the effect of the geometric shape for an office on its annual cooling and total energy use. The same objective was addressed by AlAnzi et al. [8]. The studies take into account several building forms including rectangular, L-shape, Ushape, and H-shape. For this purpose, a compactness index was used to assess the impact of shape on the energy efficiency of office buildings. Furthermore, in previous work, Danielski et al. [9] have shown that designing buildings with lower shape factor will result in lower specific heat demand; the impact of this parameter factor varies significantly as function of different thermal envelope properties for different climate circumstances. For an appropriate occupation scenario, the change in specific heat demand varied from 12 to $52 \mathrm{kWh} / \mathrm{m}^{2} /$ year. The shape factor has a sensible impact on this specific heat demand with lower thermal properties and for cold climates.

Additionally, a large number of contributions have used only roof area to calculate the energy saving of green roofs. The main objective pursued by Park [10] was to conclude the most effective building to install green roofs in Harrisburg. All finding results demonstrated that indoor temperature of buildings and energy demands are affected by building 
shapes. An experimental study was carried out to determine the relationship between building compactness and indoor temperature after the integration of green roofs during the summer season. The approach adopted was based on four physical models tested for 54 days. Indoor temperatures can be reduced by $8.1{ }^{\circ} \mathrm{C}$ for a less compact building compared to a more compact building $\left(4.6{ }^{\circ} \mathrm{C}\right)$. These results are more apparent on warm days. Another paper [11] aims to set a new understanding for building compactness assessment which can contribute to originate building morphologies in terms of comfort and thermal performance. On the basis of the cost optimal level methodology, some authors [12] have announced that the choice of the best energy efficiency measures underlined the importance of the building typology. Another research work led by Kadraoui et al [13] confirmed that the building envelope is the main source of heat loss. The integration of passive architectural concepts (such as compactness) is required to improve the building's energy performance.

In the field study of thermal buildings, a change in the size, particularly the concept height, without variation of the ceiling and floor surfaces, systematically causes a change in compactness index. This article wants to emphasize the effect of the building compactness by addressing such issues as the height of buildings and the different contact modes with the external environment. The assessment criteria will be based on a well-defined lifestyle and occupancy scenario, the indoor comfort temperature and the required energy consumption expressed in $\mathrm{Kwh} / \mathrm{year} / \mathrm{m}^{2}$. It should be noted that the few existing works in these severe conditions (Saharan climate) do not deal properly with the problem. In addition, the uniqueness and asset of this contribution consist in applying a specific method to label any building and estimate energy needs. The combination of different approaches provided a new performing model.

\section{GHARDAÏA CLIMATE AND CASE STUDIES}

Ghardaïa (latitude $32.48^{\circ} \mathrm{N}$, longitude $3.80^{\circ} \mathrm{E}$ ) has a hot, dry and desert climate, the region is noticeable by large temperature differences with a clarity index of 0.8 . It has a very important rate of insolation ( $75 \%$ on average) and the mean annual of global solar radiation measured on horizontal plane exceeds $20\left(\mathrm{MJ} / \mathrm{m}^{2}\right)$. The sunshine duration is more than 3000 hours per year, which promotes the use of solar energy in various fields [14]. The lowest sunshine duration is registered in December with 234.5 hours; the highest values were recorded during July with 337.3 hours. The average sunshine duration between 2000 and 2009 was 3391.20 hours per year i.e. approximately 9 hours per day. The annual average temperature is about $22.61^{\circ} \mathrm{C}$. Minimum temperatures of the coldest month are observed during the month of January with $5.5^{\circ} \mathrm{C}$, while maximum temperatures of the warmest month are observed during the month of July with $41.7^{\circ} \mathrm{C}$ [15]. The relative humidity is very low; it is of the order of $21.60 \%$ in July, reaching a maximum of $55.80 \%$ in January and an annual average of $38.33 \%$ [16].

The proposed study is focused on a residential building subjected to the Ghardaiia climate. This building has a living space of $92 \mathrm{~m}^{2}$ (72.62\% of the total area), the height of the walls is $3 \mathrm{~m}$. Detailed overviews of the descriptive plan of this building are given in Figure 1. The different configurations of the roofs, ground and opaque walls are illustrated in Figure 2.

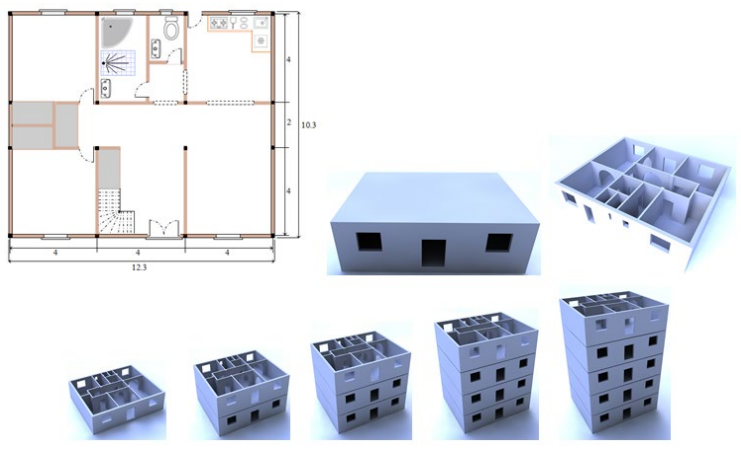

Figure 1. Descriptive plane, 2D and 3D Building modelling: Ground floor building and construction of single-to-four storey building

\section{ENERGY-BALANCE MODEL}
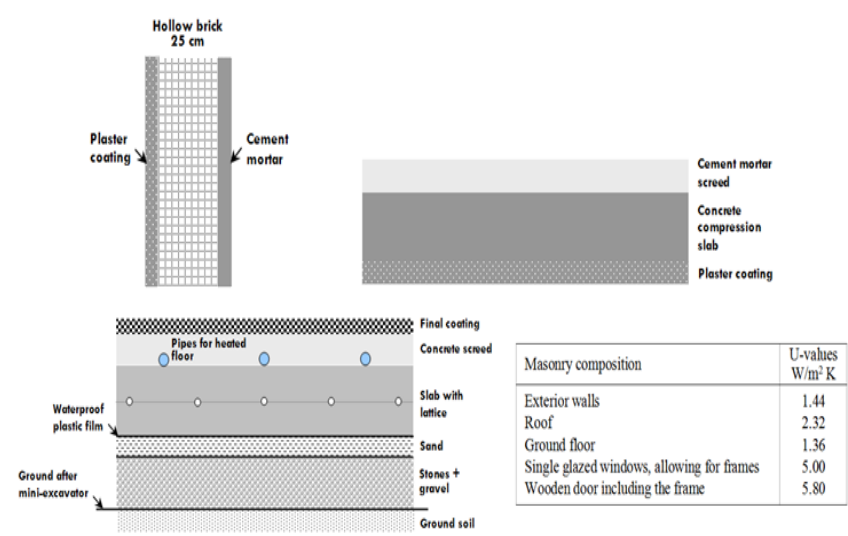

Figure 2. Masonry composition and building material proprieties

The energy balance has to deal with the physical parameters, thermal properties, building design, climatic conditions....etc.

In the heating season and during inter-seasons, consumption and heating energy needs for buildings are given by the following formula [17-18]:

$Q_{\text {Needs }}=\left|Q_{\text {Envelop }}-\left(Q_{\text {Occup }}+Q_{E l c}\right) \pm Q_{\text {Solar }}\right|+Q_{D H W}+Q_{\text {tot_elec_appl }}$

In the cooling season, equation 2 has to be used [17-18]:

$Q_{\text {Needs }}=Q_{\text {Envelop }}^{+}\left(Q_{\text {Occup }}+Q_{E l d}\right)+Q_{D H W}+Q_{\text {tot_elecppl }}+Q_{\text {Solar }}$

\subsection{Energetic needs due to the building thermal envelope}

Heating or/and cooling needs due to the building thermal envelope are defined by equation 3 [17-18]:

$$
Q_{\text {Envelop }}=24 D P_{\text {envelop }} D j
$$

Detailed calculations are provided in reference [19-20].

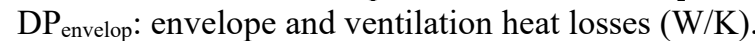

$\mathrm{Dj}$ : numbers of degree-days. 


\subsection{Domestic hot water "DHW" Requirements}

To compute the DHW needs, the calculation should be based on the equation below. In any event, it is considered that the required volume of the hot water is 50 litters of hot water at $50{ }^{\circ} \mathrm{C}$ per day per person. Energy needs for the DHW production is given by the following equation [17-18]:

$$
Q_{D H W}=1.162 \&_{D H W} N b_{\text {scup }}\left(T_{D H W} T_{C W}\right)
$$

QDHW: energy needs required to produce DHW for one day, in $\mathrm{Wh}$

$\mathrm{V}_{\text {DHW: }}$ required volume of the hot water (litters)

$\mathrm{Nb}_{\text {occp }}$ : number of persons occupying the building

$\mathrm{T}_{\mathrm{DHW}}$ : temperature of the hot water at the filling point $\left({ }^{\circ} \mathrm{C}\right)$.

$\mathrm{T}_{\mathrm{CW}}$ : average monthly temperature of the cold water entering the storage tank or the DHW production coil (instant production).

\subsection{Internal heat gains}

The human being diffuses radiations in sensible (by the body at $37^{\circ} \mathrm{C}$ ) and latent (by the production of water vapor via respiration and perspiration) heat form. Different values are given in the literature [17-18], the heat diffusion (W) from the occupants' activities are given by Table 1 . The general equation that gives the values of internal gains is given by the following expression:

$$
Q_{\text {Occup }}=C p N b_{\text {ccup }} D_{\text {pres/da }} N b_{h e a t e d+d i}
$$

$\mathrm{Cp}$ : the amount of heat given off by occupant (W/occupant).

$\mathrm{D}_{\text {pres/day: }}$ the period of presence during the day (h/day).

$\mathrm{Nb}_{\text {heated days }}$ : Number of heated days (days/year).

The total amount of heat released by both equipment and lighting is determined according to the use and ignition mode of these electrical appliances. In this context, average values (default values) were adopted to define the internal loads in a building (Table 2).

Table 1. Cp \& radiated heat per person [17-18]

\begin{tabular}{cc}
\hline Examples of activities & $\begin{array}{c}\text { Heat diffusion per person } \\
\text { (sensible and latent) }\end{array}$ \\
\hline $\begin{array}{c}\text { Static sitting activities (read and } \\
\text { write) }\end{array}$ & $120 \mathrm{~W}$ \\
$\begin{array}{c}\text { Simple works that can be done } \\
\text { either sitting or standing, laboratory } \\
\text { work, typewriter... }\end{array}$ & $150 \mathrm{~W}$ \\
Light physical activities & 190 \\
Medium to difficult bodily activities & More than $200 \mathrm{~W}$ \\
\hline
\end{tabular}

\begin{tabular}{|c|c|c|c|c|c|}
\hline & \multicolumn{4}{|c|}{$\begin{array}{c}\text { Duration (hours) and operating power } \\
\text { modes (Watts) }\end{array}$} & \multirow[t]{2}{*}{$\begin{array}{c}\text { Energy } \\
\text { (Wh) }\end{array}$} \\
\hline & $\begin{array}{c}\text { Mode } \\
1\end{array}$ & $\begin{array}{c}\text { Number of } \\
\text { hours }\end{array}$ & $\begin{array}{c}\text { Mode } \\
2\end{array}$ & $\begin{array}{c}\text { Number of } \\
\text { hours }\end{array}$ & \\
\hline $\begin{array}{c}\text { LCD TV }+ \\
\text { Integrated demo }\end{array}$ & 20 & 19 & 78 & 5 & 1540 \\
\hline Refrigerator & \multicolumn{4}{|c|}{ Total par jour } & 552 \\
\hline Lighting & 75 & 21.75 & & & 1631.3 \\
\hline $\begin{array}{l}\text { Flat screen } \\
\text { computer }\end{array}$ & 32 & 2 & 186 & 4 & 808 \\
\hline \multicolumn{5}{|c|}{ Total par jour } & $\begin{array}{c}1200 \\
5731.3\end{array}$ \\
\hline
\end{tabular}

Table 2. Cp \& radiated heat per person [17-18]

\subsection{Internal heat gains}

Three input data must be taken into account according 1200 to Table 3.

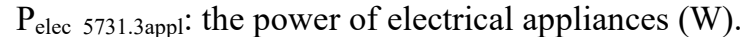

$\mathrm{Nb}_{\text {hours: }}$ the number of hours when the device is in an operational state during the day.

$\mathrm{Nb}_{\text {days: }}$ : the number of days when the device is in an operational state during the year. Calculation, in kilowatthours, shall be as follows:

$$
Q_{\text {tot_elec_a ppl }}=N b_{\text {hours }} N b_{\text {days }} \frac{P_{\text {elec_appl }}}{1000}
$$

Table 3. Average energy consumption per day for electrical appliances [17-18]

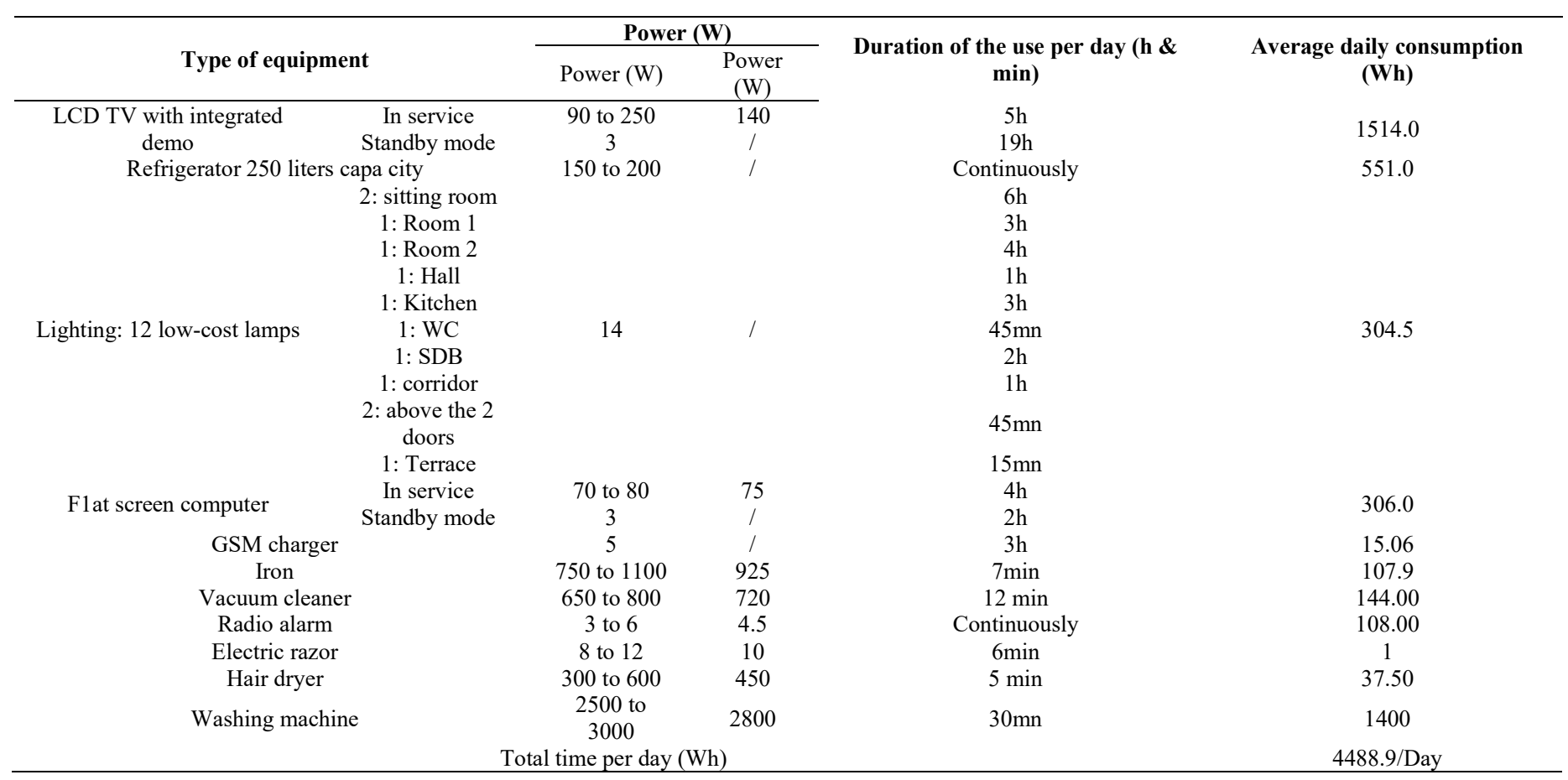




\subsection{Passive solar gains}

The solar gains depend on the incident solar radiation, the orientation of the receiving surfaces and some characteristics such as: shading, transmission and absorption coefficients. This energy gain will be calculated according to the following equation $[17,19]$ :

$$
Q_{\text {Solar }}=\sum_{j} I_{S j} \sum_{n}\left(A F_{\text {Shad }} F_{\text {Red }} g\right)_{n j}
$$

The first sum is made on all orientations $\mathrm{j}$; the second is applicable on all surfaces $\mathrm{n}$ in different orientations " $\mathrm{j}$ " Is: solar irradiation per area unit $\left(\mathrm{Wh} / \mathrm{m}^{2}\right)$

$\mathrm{F}_{\text {Red: }}$ reduction factor for window frames, equal to the ratio of the transparent surface of the window to its total area; its value is set at 0.8

$\mathrm{F}_{\text {Shad: }}$ shading factor; its value is set at 0.7

$\mathrm{g}$ : solar factor of the bay window; its value is set at 0.8 for single-glazed windows.

\section{COMPACTNESS AND BUILDING HEIGHT CONCEPT, COMPARATIVE ANALYSIS OF ENERGY CONSUMPTION}

Before proceeding with the comparative study, it is preferable to draw up a summary table (4) giving the common energy parameters of all the cases to be studied. The attention paid to the average outside air temperature of the month in question, comfort temperature which was set between 21 and $26^{\circ} \mathrm{C}$, monthly temperature of the cold water, passive solar gain, monthly values of internal gains, energetic hot water needs of a single-family home and the equivalent electricity consumption for one family home. The other selected input parameters are as follows: $\mathrm{T}_{\mathrm{DHW}}=50^{\circ} \mathrm{C}, \mathrm{Cp}=$ $150 \mathrm{~W}, \mathrm{Nb}_{\text {occp }}=5, \mathrm{D}_{\text {pres/day }}=15 \mathrm{~h}$, the glass surface amount to about $95 \%$ of the window area, $\mathrm{F}_{\text {Shad }}=0.7$ for south orientation, $\mathrm{F}_{\mathrm{Red}}=0.8$ and $\mathrm{g}=0.8$.

Table 4. Monthly values of the common energy parameters of all the cases to be studied

\begin{tabular}{|c|c|c|c|c|c|c|c|c|}
\hline & \multirow{2}{*}{$\mathbf{T}_{\text {out }}$} & \multirow{2}{*}{$\mathbf{T}_{\text {conf }}$} & \multirow{2}{*}{$\mathbf{T}_{\mathrm{cw}}$} & \multirow{2}{*}{$\mathbf{Q}_{\text {solar }}$} & \multicolumn{2}{|c|}{ Internal heat gains (kWh) } & \multirow{2}{*}{$Q_{b H w}(k W h)$} & \multirow{2}{*}{$Q_{\text {Elec }}(\mathbf{k W h})$} \\
\hline & & & & & Q occup & $Q_{\text {Elc }}$ & & \\
\hline January & 10.1000 & 21.0000 & 7.0000 & 394.5667 & 348.7500 & 177.6703 & 387.5031 & 139.1559 \\
\hline February & 12.3000 & 21.0000 & 9.0000 & 338.8108 & 315.0000 & 160.4764 & 333.7236 & 125.6892 \\
\hline March & 15.3000 & 21.0000 & 11.5000 & 323.4353 & 348.7500 & 177.6703 & 346.9504 & 139.1559 \\
\hline April & 20.0000 & 21.0000 & 13.0000 & 0 & 337.5000 & 171.9390 & 322.6770 & 134.6670 \\
\hline May & 24.5000 & 24.5000 & 16.0000 & 0 & 348.7500 & 177.6703 & 306.3978 & 139.1559 \\
\hline June & 29.7000 & 26.0000 & 19.0000 & 0 & 337.5000 & 171.9390 & 270.3510 & 134.6670 \\
\hline July & 33.4000 & 26.0000 & 21.0000 & 0 & 348.7500 & 177.6703 & 261.3393 & 139.1559 \\
\hline August & 32.7000 & 26.0000 & 20.0000 & 0 & 348.7500 & 177.6703 & 270.3510 & 139.1559 \\
\hline September & 27.8000 & 26.0000 & 17.5000 & 0 & 337.5000 & 177.9390 & 283.4325 & 134.6670 \\
\hline October & 20.7000 & 21.0000 & 15.0000 & 0 & 348.7500 & 177.6703 & 315.4095 & 139.1559 \\
\hline November & 14.4000 & 21.0000 & 11.0000 & 354.1864 & 337.5000 & 171.9390 & 340.1190 & 134.6670 \\
\hline December & 10.7000 & 21.0000 & 8.0000 & 348.3617 & 348.7500 & 177.6703 & 378.4914 & 139.1559 \\
\hline & & & & & & & $3.816710^{3}$ & $1.638410^{3}$ \\
\hline
\end{tabular}

\subsection{Without thermal insulation}

Table 5. Monthly and annual energy needs to maintain comfort between 21 and $26{ }^{\circ} \mathrm{C}$

\begin{tabular}{|c|c|c|c|c|c|c|c|c|c|c|c|c|c|}
\hline $\mathbf{n}$ & 1 & $\begin{array}{c}\mathbf{R}+1 \\
\mathbf{2} \\
\end{array}$ & $\begin{array}{c}\mathbf{R}+2 \\
\mathbf{3} \\
\end{array}$ & $\begin{array}{c}R+3 \\
4 \\
\end{array}$ & $\begin{array}{c}\mathrm{R}+4 \\
5\end{array}$ & $\begin{array}{c}R+5 \\
6 \\
\end{array}$ & $\begin{array}{c}\mathrm{R}+6 \\
7 \\
\end{array}$ & $\begin{array}{c}\mathrm{R}+7 \\
8 \\
\end{array}$ & $\begin{array}{c}\mathbf{R}+8 \\
9 \\
\end{array}$ & $\begin{array}{c}\mathrm{R}+9 \\
10\end{array}$ & $\begin{array}{c}\mathrm{R}+10 \\
11\end{array}$ & $\begin{array}{c}\mathrm{R}+11 \\
12 \\
\end{array}$ & $\begin{array}{c}R+12 \\
13 \\
\end{array}$ \\
\hline $\mathrm{S} / \mathrm{V}$ & 0.690 & 0.523 & & & & & & & & & & & \\
\hline & 1 & 4 & 0.4679 & 0.4401 & 0.4234 & 0.4123 & 0.4044 & 0.3984 & 0.3938 & 0.3901 & 0.3871 & 0.3846 & 0.3824 \\
\hline Jan & 7404 & 10277 & 13150 & 16022 & 18895 & 21767 & 24640 & 27512 & 30385 & 33258 & 36130 & 39003 & 41875 \\
\hline Feb & 5258 & 7250 & 9242 & 11234 & 13226 & 15218 & 17210 & 19202 & 21193 & 23185 & 25177 & 27169 & 29161 \\
\hline Mar & 3694 & 5025 & 6355 & 7685 & 9015 & 10346 & 11676 & 13006 & 14337 & 15667 & 16997 & 18327 & 19658 \\
\hline Apr & 632 & 964 & 1646 & 2327 & 3008 & 3690 & 4371 & 5052 & 5734 & 6415 & 7097 & 7778 & 8459 \\
\hline May & 972 & 1944 & 2916 & 3888 & 4860 & 5832 & 6804 & 7776 & 8748 & 9720 & 10692 & 11664 & 12636 \\
\hline Jun & 3473 & 5449 & 7424 & 9399 & 11374 & 13349 & 15324 & 17299 & 19274 & 21250 & 23225 & 25200 & 27175 \\
\hline Jul & 6285 & 9417 & 12549 & 15682 & 18814 & 21946 & 25078 & 28211 & 31343 & 34475 & 37607 & 40740 & 43872 \\
\hline Aug & 5774 & 8705 & 11635 & 14566 & 17496 & 20426 & 23357 & 26287 & 29218 & 32148 & 35078 & 38009 & 40939 \\
\hline Sep & 2165 & 3607 & 5049 & 6491 & 7933 & 9375 & 10816 & 12258 & 13700 & 15142 & 16584 & 18026 & 19468 \\
\hline Oct & 769 & 1662 & 2554 & 3447 & 4340 & 5232 & 6125 & 7018 & 7910 & 8803 & 9695 & 10588 & 11481 \\
\hline Nov & 4163 & 5676 & 7188 & 8700 & 10212 & 11724 & 13236 & 14749 & 16261 & 17773 & 19285 & 20797 & 22309 \\
\hline Dec & 7009 & 9736 & 12463 & 1.519 & 17917 & 20644 & 23371 & 26098 & 28825 & 31552 & 34279 & 37006 & 39733 \\
\hline Tot & & & & 11463 & 13709 & 15955 & 18201 & 20447 & 22693 & 24939 & 27185 & 29431 & 31677 \\
\hline $\begin{array}{c}\text { (kWh/year) } \\
\text { Tot/S }\end{array}$ & 47600 & 69711 & 92170 & 0 & 0 & 0 & 0 & 0 & 0 & 0 & 0 & 0 & 0 \\
\hline$\left(\mathrm{kWh} / \mathrm{m}^{2} /\right.$ year & 375.7 & 275.1 & 242.5 & & & & & & & & & & \\
\hline$)$ & 2 & 2 & 1 & 226.2 & 216.42 & 209.89 & 205.23 & 201.74 & 199.02 & 196.85 & 195.07 & 193.59 & 192.33 \\
\hline
\end{tabular}

$\mathrm{n}$ : the number of family houses in the entire building. S: The outer surface of the walls $\left(\mathrm{m}^{2}\right) . \mathrm{V}$ : total volume of the entire building $\left(\mathrm{m}^{3}\right) . \mathrm{S} / \mathrm{V}$ : the compactness index 
The approach is based on an in-depth study of the difference between several identical family houses. This similarity concerns the entire characteristics: thermo-physical properties of the building envelope, structural element dimensions, occupant lifestyles and their desired comfort temperatures. The only difference is in its implantation in the building. The results that will be provided will therefore be expressed in $\mathrm{kWh} / \mathrm{m}^{2} / \mathrm{an}$. These unit values represent the average annual energy requirements even for a family home located in the same building. It is reminded that each house of the same building is characterized by the same properties previously announced. The calculation program designed for this purpose gives us the opportunity to calculate the energy needs of a house exposed at all levels. It is also feasible to study buildings containing several floors and family houses. Table 5 provides results for calculating monthly and annual energy requirements of the different cases. In this regard, a comparison can be made between a single-family home at all levels and a multi-family building, including the number of floors in question.

In order to perform a consistent comparative study, the method would refer to the various buildings shown in figure 1 , going up to the twelfth floor.
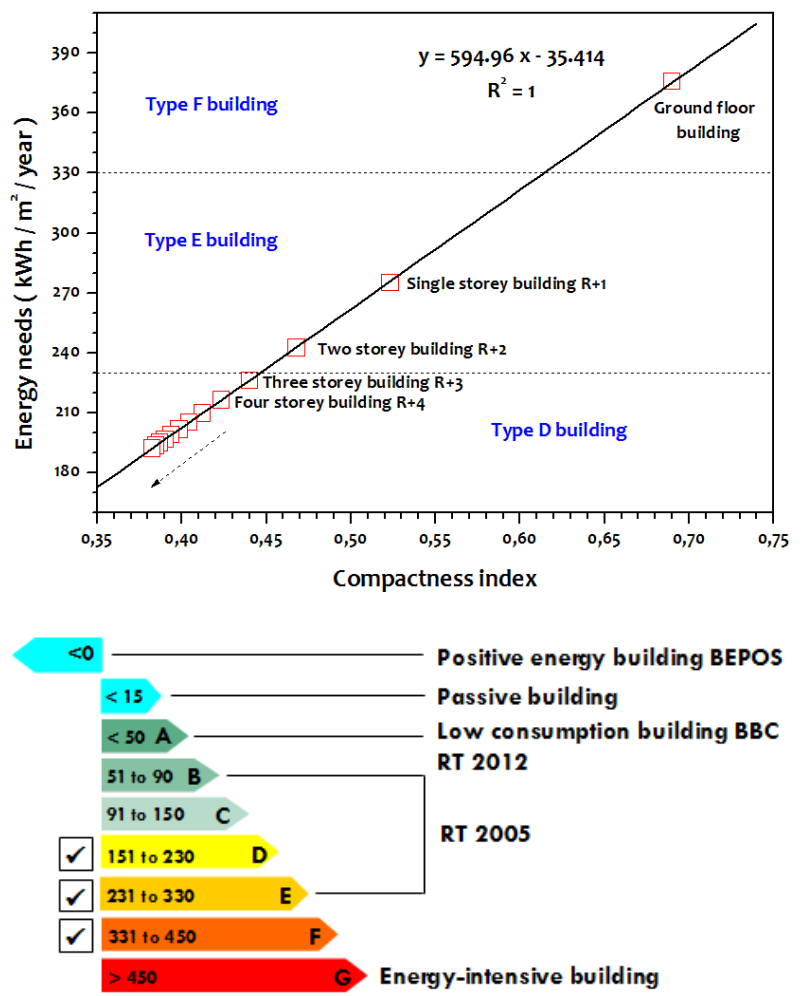

Figure 3. Energy needs according to the number of floors and building labeling scheme $\left(\mathrm{kWh} / \mathrm{m}^{2} /\right.$ year $)$

Energy needs vary linearly in accordance with compactness index; the corresponding equation is shown in the figure. The difference between the total energy loads is sometimes radical; these buildings will join the constructions that have an energy label of type F, E or D. This indicates that in this case, it is necessary to favor large buildings to rationalize energy consumption. In addition, the obtained results indicate that the convergence of values (by increasing the number of floors, i.e. by improving the building compactness and reducing the compactness index) towards smaller values was very fast at first, but beyond a certain level, this convergence will not become interesting. To be more precise, it was necessary to trace the variation in energy savings according to the number of floors (figure 4).

In comparison with the values in the above figure, it has been found that an energy saving of exactly $26.77 \%$ can be achieved just by varying a single house to one-storey building. By crossing the fourth-storey building, i.e. for a construction with five family houses $(n=5)$, it will have more substantial savings that exceed $40 \%$ but with a clear stability of the values. This variation is translated by a polynomial regression model of order 6 .

\subsection{With thermal insulation}

In this section, the same research work is conducted with an external integration of a thermal insulation covering the whole envelope surface (thermal conductivity $\lambda=0.04 \mathrm{~W} / \mathrm{m}$ $\mathrm{K}$, and a thickness of $10 \mathrm{~cm}$ ). Table 6 summarizes the calculation results regarding the monthly and annual energy needs in different cases. Accordingly, the comparative study between the different buildings (up to the eleven storey building) is shown in figures 5 and 6 .

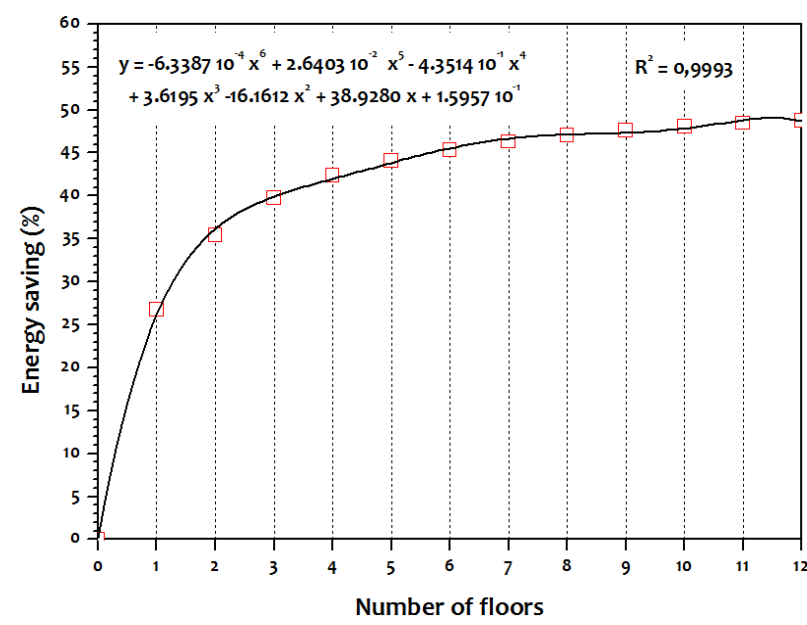

Figure 4. Annual energy savings according to the number of floors by referring to the single family house exposed to all levels

The obtained results generally raise the same remarks. The regression equation shows that the variation between energy needs and compactness index is also linear.

With the exception of the first case (only one family house exposed at all levels), the others can be integrated in the buildings that have an energy label of "type C". It was reconfirmed that it was essential to privilege large building constructions. Similarly, the convergence towards smaller values was at first very fast and beyond a certain level this convergence will not become interesting. On the basis of the calculated data, an energy gain of exactly $21.17 \%$ can be saved by varying a single house to one-storey building. This value seems less important compared to the first case but it is still interesting in terms of energy saving. On the three storey building, the reduction in energy use exceeds $35 \%$ but remains below $38.5 \%$. This variation is translated by a precise regression polynomial model of order 6 . Otherwise, it is possible to study the relationship between thermal insulation and compactness. This is the reason why we are led to trace the variation of the energy consumption reduction due to the thermal insulation as a function of the compactness index (Figure 7). 
Table 6. Monthly and annual energy needs to maintain comfort between 21 and $26^{\circ} \mathrm{C}$, case of a building envelope insulated by $10 \mathrm{~cm}$ thick

\begin{tabular}{|c|c|c|c|c|c|c|c|c|c|c|c|c|c|}
\hline n & 1 & $\begin{array}{c}\mathrm{R}+\mathrm{l} \\
\mathbf{2}\end{array}$ & $\begin{array}{c}\mathbf{R}+2 \\
3 \\
\end{array}$ & $\begin{array}{c}R+3 \\
4 \\
\end{array}$ & $\begin{array}{c}R+4 \\
5 \\
\end{array}$ & $\begin{array}{c}R+5 \\
6 \\
\end{array}$ & $\begin{array}{c}R+6 \\
7 \\
\end{array}$ & $\begin{array}{c}\mathbf{R}+7 \\
8 \\
\end{array}$ & $\begin{array}{c}\mathbf{R}+8 \\
9 \\
\end{array}$ & $\begin{array}{c}\mathrm{R}+9 \\
10 \\
\end{array}$ & $\begin{array}{c}\mathrm{R}+10 \\
11 \\
\end{array}$ & $\begin{array}{c}\mathrm{R}+11 \\
12\end{array}$ & $\begin{array}{c}\mathrm{R}+12 \\
13\end{array}$ \\
\hline $\mathrm{S} / \mathrm{V}$ & 0.6901 & 0.5234 & 0.4679 & 0.4401 & 0.4234 & 0.4123 & 0.4044 & 0.3984 & 0.3938 & 0.3901 & 0.3871 & 0.3846 & 0.3824 \\
\hline Jan & 2621.3 & 3614.3 & 4607.2 & 5600.2 & 6593 & 7586 & 8579 & 09572 & 10565 & 11558 & 12551 & 13544 & 14537 \\
\hline Feb & 1812.1 & 2451.4 & 3090.6 & 3729.9 & 4369 & 5008 & 5648 & 06287 & 06926 & 07565 & 08205 & 08844 & 09483 \\
\hline Mar; & 1197.2 & | 1548.7 & 1900.1 & 2251.6 & 2603 & 2954 & 3500 & 04120 & 04741 & 05362 & 05983 & 06603 & 07224 \\
\hline Apr & 0706.2 & 1553.1 & 2400 & 3247 & 4094 & 4941 & 5788 & 06635 & 7482 & 08329 & 09175 & 10022 & 10869 \\
\hline May & 0972 & 1943.9 & 2915.9 & 3887.9 & 4860 & 5832 & 6804 & 07776 & 8748 & 09720 & 10692 & 11664 & 12636 \\
\hline Jun & 1905.7 & 3266.9 & 4628.2 & 5989.4 & 7351 & 8712 & 10073 & 11434 & 12796 & 14157 & 15518 & 16879 & 18241 \\
\hline Jul & 3041.1 & 4900.9 & 6760.7 & 8620.4 & 10480 & 12340 & 14200 & 16060 & 17919 & 19779 & 21639 & 23499 & 25358 \\
\hline Aug & 2838.3 & 4617.2 & 6396.1| & 8175 & 9954 & 11733 & 13512 & 15291 & 17070 & 18849 & 20627 & 22406 & 24185 \\
\hline Sep & 1402.6 & 2546.4 & 3690.1 & 4833.9 & 5978 & 7121 & 8265 & 9409 & 10553 & 11696 & 12840 & 13984 & 15128 \\
\hline Oct & 0900.5 & 1844.4 & 2788.3 & 3732.2 & 4676 & 5620 & 6564 & 7508 & 8452 & 09396 & 10339 & 11283 & 12227 \\
\hline Nov & 1364.5 & 1779.1 & 2193.6 & 2608.2 & 3023 & 3437 & 3852 & 4266 & 4681 & 05096 & 05510 & 05925 & 06339 \\
\hline Dec & 2490.4 & 3442.1 & 4393.7 & 5345.4 & 6297 & 7249 & 8200 & 9152 & 10104 & 11055 & 12007 & 12958 & 13910 \\
\hline Tot(kWh/year) & 21252 & 33508 & 45765 & 58021 & 70277 & 82534 & 94984 & 107510 & 120040 & 132560 & 145090 & 157610 & 170140 \\
\hline $\operatorname{TotS}\left(\mathrm{kWh} / \mathrm{m}^{2} /\right.$ year $)$ & 167.75 & 132.24 & 120.41 & 114.49 & 110.94 & 108.58 & 107.1 & 106.07 & 105.27 & 104.63 & 104.11 & 103.67 & 103.3 \\
\hline
\end{tabular}

The advantage of the external thermal insulation is to increase significantly the overall thermal performance of the building, which promotes a significant reduction in heating and cooling costs and improves thermal comfort. It has also been found that this advantage gradually decreases by improving the building compactness (by adding additional floors). This aspect can be translated by the nonlinear curve indicated in the previous figure. Furthermore, at the beginning, the decrease is consistent, considering a twostorey building (energy saving of $55.35 \%$ ) instead of a single family home (energy saving of $51.93 \%$ ), a difference of $3.42 \%$ can be seen. This gap will be quickly amortized; it becomes $0.47 \%$ from a four-story building to a five-storey building and $0.16 \%$ from an eleven-story building to a twelve-storey building.

To integrate this passive concept, it is compulsory to study the techno-economic aspect which must therefore have a particular interest in these similar situations. This is the reason why we will be interested in the return time on investment. The method consists firstly in estimating the total cost resulting from the isolation procedure by adding the total cost of the isolation procedure defined by the sum of the polystyrene price and the cost of all insulation works (3000 $\left.\mathrm{DZD} / \mathrm{m}^{2}\right)$, and the annual energy bill. The retained price of a polystyrene plate $\left(5 \mathrm{~cm}\right.$ thick layer and $2 \mathrm{~m}^{2}$ of surface area) is fixed at $600 \mathrm{DZD}$.

The variation of the return time on investment, expressed by the number of months, is the ratio of the extra cost (the total cost of the isolation procedure - the initial bill without thermal insulation) multiplied by 12 and the annual financial gain which is defined by the difference between the initial bill (without thermal insulation) and the energy bill in the case of thermal insulation. Figure 8 focuses on the effectiveness of this passive aspect and their financial impact on the investment-return time.

The figure indicates that the investment-return time decreases slightly by transiting to a building with an upper floor. In this respect, it is worth noting that it took 4 years and 5 days to recover the expensed amount for a $10 \mathrm{~cm}$ layer of thermal insulation in the case of a single house. For a single storey building, it is possible to reduce this period to only 3 years, 10 months and 27 days. By changing a singlestorey building to a two-storey building, the investmentreturn time will be decreased by 22 additional days. For higher floors, it will be possible to obtain greater savings but with a better stability. Generally, the investment-return time is between 49 months and 44 months.

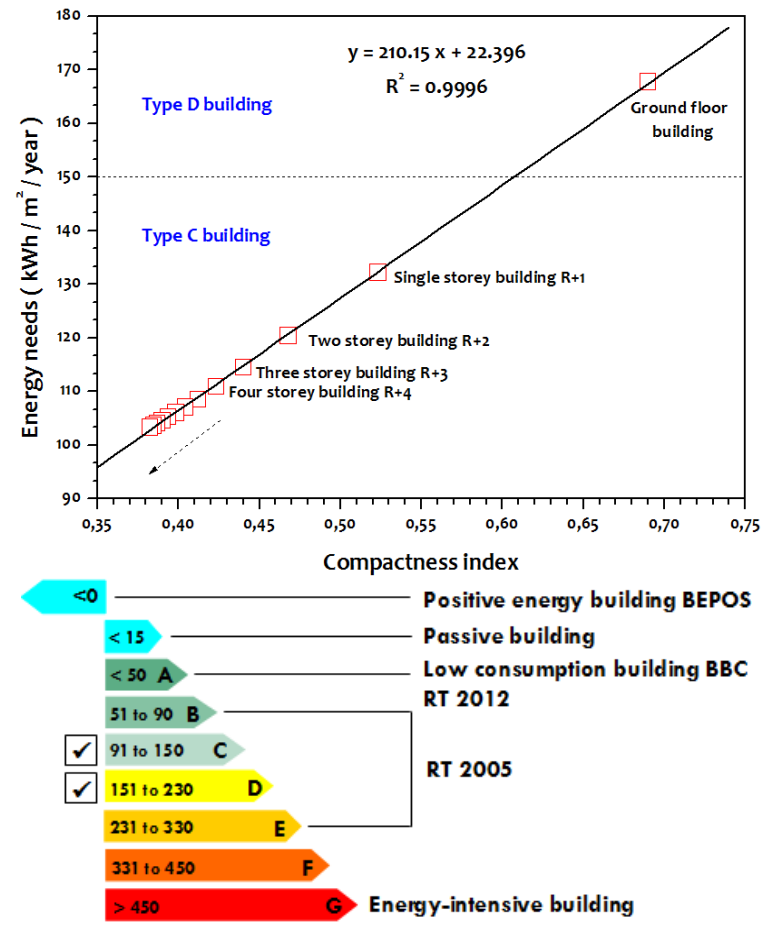

Figure 5. Energy needs according to the number of floors and building labeling scheme $\left(\mathrm{kWh} / \mathrm{m}^{2} /\right.$ year $)$, case of a building envelope insulated by $10 \mathrm{~cm}$ thick

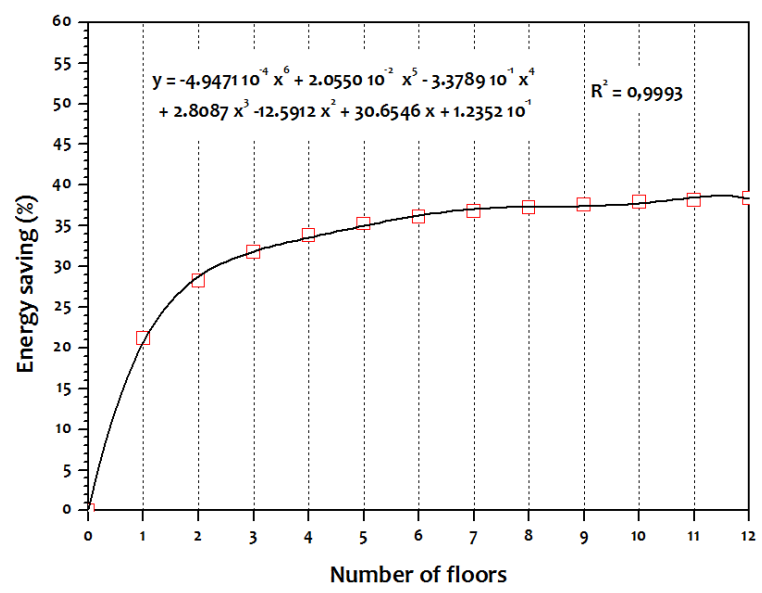

Figure 6. Annual energy savings according to the number of floors by referring to the single family house exposed to all levels, case of a building envelope insulated by $10 \mathrm{~cm}$ thick 


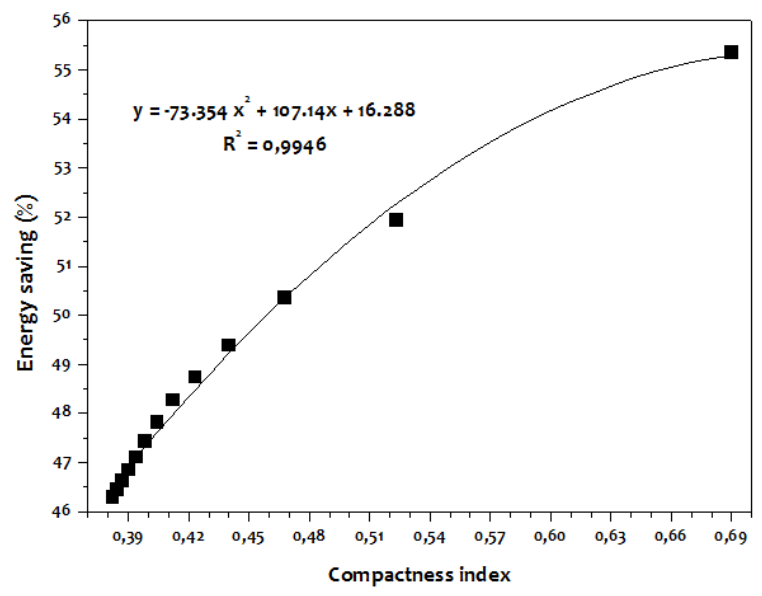

Figure 7. Decrease in energy needs due to thermal insulation $(10 \mathrm{~cm})$ as a function of the building compactness index

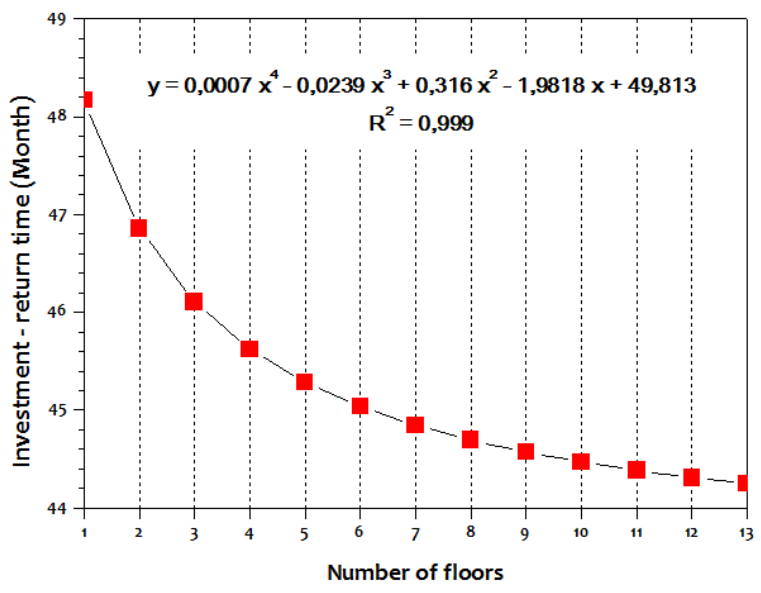

Figure 8. Variation of the return time on investment according to the cost of the number of floors

\section{FINDING CONCLUSIONS}

The main objective of this accomplished research work is to examine the impact of the building height concept on energy needs. It takes into account the variation of the depreciative surfaces in contact with the external environments. According to the results, and under several conditions, compactness can contribute to the improvement of thermal comfort and to the minimization of the energy requirements. The contact mode and the height of the building influence the building energy demand.

The compactness index defined as the ratio between the envelope surface and the inner volume of the building. The running of reliable prediction models and their relative simplicity allow them to be used as a tool for estimating the different physical quantities (energy needs, energy savings and investment-return time). Optimal compactness results in minimal thermal losses, that are why, to compensate the increased energy needs due to the lower compactness of the building, one can, increase the insulation level of the building envelope.

The absence of insulation would result in an energy saving of exactly $26.77 \%$, by raising a single house to one-storey building. It will be more substantial savings (more than $40 \%$ ) by exceeding the fourth floor. In the case of an insulating layer of $10 \mathrm{~cm}$, an energy gain of $21.17 \%$ can be saved by varying a single house to one-storey building. The reduction in energy needs exceeds $35 \%$ but remains below $38.5 \%$ for buildings which are over three storeys high.

Generally, the investment-return time is between 49 months and 44 months, and it is inversely proportional to the number of storeys in the dwelling.

Optimal compactness serves to minimize the energy needs of the buildings, which will systematically reduce the required level of thermal insulation. It is therefore necessary to favor large buildings to rationalize energy consumption.

\section{REFERENCES}

[1] Kouidri, M.A., Bessissa, L., Mahi, D., Hadjadj, A. (2019). Experimental environmental study of atmospheric emissions in the urban area of the industrial city of Hassi R'mel. Modelling, Measurement and Control C, $\quad 80(1)$ : $\quad 1-4$. https://doi.org/10.18280/mmc_c.800101

[2] Marta, M., Belinda, L.M. (2017). Simplified model to determine the energy demand of existing buildings, case study of social housing in Zaragoza, Spain. Energy and Buildings, 149: 483-493. https://doi.org/10.1016/j.enbuild.2017.04.039

[3] Li, W.W., Goodchild, M.F., Church, R. (2013). An efficient measure of compactness for two-dimensional shapes and its application in regionalization problems. International Journal of Geographical Information Science, 27(6): 1227-1250. http://dx.doi.org/10.1080/13658816.2012.752093

[4] Bansal, N.K., Bhandari, M.S., Kumar, P.S. (2001). Building components and energy efficiency in buildings. International Journal of Ambient Energy, 22(3): 123131. https://doi.org/10.1080/01430750.2001.9674847

[5] Parasonis, J., Keizikas, A., Kalibatiene, D. (2012). The relationship between the shape of a building and its energy performance. Architectural Engineering and Design Management, 8(4): 246-256. https://doi.org/10.1080/17452007.2012.675139

[6] Ali-Toudert, F., Weidhaus, J. (2017). Numerical assessment and optimization of a low-energy residential building for Mediterranean and Saharan climates using a pilot project in Algeria. Renewable Energy, 101: 327346. https://doi.org/10.1016/j.renene.2016.08.043

[7] Ourghi, R., Al-Anzi, A., Krartti, M. (2007). A simplified analysis method to predict the impact of shape on annual energy use for office buildings. Energy Conversion and Management, 48(1): 300-305. https://doi.org/10.1016/j.enconman.2006.04.011

[8] AlAnzi, A., Seo, D., Krart, M. (2009). Impact of building shape on thermal performance of office buildings in Kuwait. Energy Conversion and Management, $\quad 50(3)$ : $\quad 822-828$. https://doi.org/10.1016/j.enconman.2008.09.033

[9] Danielski, I., Fröling, M., Joelsson, A. (2012). The impact of the shape factor on final energy demand in residential buildings in Nordic climates. World Renewable Energy Forum, WREF, Including World Renewable Energy Congress XII and Colorado Renewable Energy Society (CRES), Denver, Colorado, USA.

[10] Park, G. (2014). Using cost-benefit analysis and building compactness to determine the most effective 
buildings to install green roofs in Harrisburg, Pennsylvania. A thesis submitted to the Department of Geography and Earth Science and the Graduate Council in partial fulfillment of the requirements for the degree of Master of Science in Geoenvironmental Studies, Shippensburg University, Shippensburg, Pennsylvania.

[11] Almumar, M.M.S. (2016). Understanding building compactness entity, definition and concept of assessment. International Transaction Journal of Engineering, Management, \& Applied Sciences \& Technologies, 7(3): 165-175. https://doi.org/10.13140/RG.2.2.15820.82569

[12] Tronchin, L., Fabbri, K., Tommasino, M.C. (2014). On the cost-optimal levels of energy performance requirements and its economic evaluation in Italy. International Journal of Sustainable Energy Planning and Management, 3: 49-62. https://doi.org/10.5278/ijsepm.2014.3.5

[13] Kadraoui, H., Bekkouche, S.M.A., Chikhaoui, A. (2019). Analysis of energy consumption for Algerian building in extreme North-African climates. International Journal of Sustainable Energy Planning and Management, 19(45-58). http://dx.doi.org/10.5278/ijsepm.2019.19.5

[14] Gairaa, K., Bakelli, Y. (2011). An overview of global solar radiation measurements in Ghardaïa area, south Algeria. International Journal of Energy and Environment, 2(2): 255-260. http://dx.doi.org/10.1163/ej.9789004175556.i-382.7

[15] Bekkouche, S.M.A., Benouaz, T., Hamdani, M., Cherier, M.K., Yaiche, M.R., Benamrane, N. (2017). Diagnosis and comprehensive quantification of energy needs for existing residential buildings under Sahara weather conditions. Advances in Building Energy Research, 11(1): $37-51$
[16] Bekkouche, S.M.A., Benouaz, T., Cherier, M.K., Hamdani, M., Yaiche, M.R., Khanniche, R. (2013). Influence of building orientation on internal temperature in Saharan climates, building located in Ghardaïa region (Algeria). International Scientific Journal, Thermal Science, $\quad$ 17(2): 349-364. https://doi.org/10.2298/TSCI110121112B

[17] Bendara, S., Bekkouche, S.M.A., Benouaz, T., Belaid, S., Hamdani, M., Cherier, M.K., Boutelhig, A., Benamrane, N. (2019). Energy efficiency and economic insulation thickness according to the compactness measure Case of a studio apartment under Saharan weather conditions. Journal of Solar Energy Engineering: Including Wind Energy and Building Energy https://doi.org/10.1115/1.4042455

[18] Belgherras, S., Bekkouche, S.M.A., Benouaz, T., Benamrane, N. (2017). Prospective analysis of the energy efficiency in a farm studio under Saharan weather conditions. Energy and Buildings, 145: 342353. https://doi.org/10.1016/j.enbuild.2017.04.030

[19] Bekkouche, S.M.A., Benouaz, T., Hamdani, M., Cherier, M.K., Yaiche, M.R., Benamrane, N. (2017). Diagnosis and comprehensive quantification of energy needs for existing residential buildings under Sahara weather conditions. Advances in Building Energy Research, 11(1): $37-51$. https://doi.org/10.1080/17512549.2015.1119059

[20] Cherier, M.K., Bekkouche, S.M.A., Benouaz, T., Belaid, S., Hamdani, M., Benamrane, N. (2018). Energy efficiency and supplement interior comfort with passive solar heating in Saharan climate. Advances in Buildi ng Energy Research. Article in press. https://doi.org/10.1080/17512549.2018.1502682 